2 DR. MAURICIO ROMERO TORRES (Orcid ID : 0000-0003-3282-0372)

3

4

5

6

7

Article type : Primary Research Articles

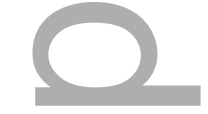

\title{
Coral Reef Resilience to Thermal Stress in the Eastern Tropical Pacific
}

Running Title: Eastern Tropical Pacific Coral Resilience

Mauricio Romero-Torres ${ }^{1,2 *}$, Alberto Acosta ${ }^{1}$, Ana M. Palacio-Castro ${ }^{3,4}$, Eric A.

Treml $^{5}$, Fernando A. Zapata ${ }^{6}$, David A. Paz-García ${ }^{7}, \&$ James W. Porter ${ }^{8}$

${ }^{1}$ Unidad de Ecología y Sistemática (UNESIS), Departamento de Biología, Pontificia

Universidad Javeriana, Carrera 7 No. 40-62, Bogotá, D.C., Colombia

${ }^{2}$ Unidad Nacional para la Gestión del Riesgo de Desastres (UNGRD), Subdirección

para el Conocimiento del Riesgo. Avenida Calle 26 No. 92-32, Edificio Gold 4 - piso 2,

Bogotá, D.C., Colombia

${ }^{3}$ Rosenstiel School of Marine and Atmospheric Science, University of Miami, 4600

Rickenbacker Causeway, Miami, F1, 33149 USA

${ }^{4}$ Atlantic Oceanographic and Meteorological Laboratory, National Oceanographic and Atmospheric Administration, Miami, FL, 33149, USA

${ }^{5}$ School of Life and Environmental Sciences, Deakin University, Waurn Ponds, VIC 3216, Australia

${ }^{6}$ Grupo de Investigación en Ecología de Arrecifes Coralinos, Departamento de Biología, Universidad del Valle, Calle 13 No. 100-00, Cali, Colombia

This is the author manuscript accepted for publication and has undergone full peer review but has not been through the copyediting, typesetting, pagination and proofreading process, which may lead to differences between this version and the Version of Record. Please cite this article as doi: 10.1111/GCB.15126

This article is protected by copyright. All rights reserved 
$34{ }^{7}$ CONACyT-Centro de Investigaciones Biológicas del Noroeste (CIBNOR). Calle IPN 195, Col. Playa Palo de Santa Rita Sur, 23096 La Paz, B.C.S., México

${ }^{8}$ Odum School of Ecology, University of Georgia, Athens, GA 30602, USA

*Contact information: Mauricio Romero, Pontificia Universidad Javeriana. Carrera 7

No. 40- 62 Ed. 52 Office 500. Bogotá, Colombia 100311. Email:

mauricio_romero@javeriana.edu.co

Coral reefs world-wide are threatened by thermal stress caused by climate change.

Especially devastating periods of coral loss frequently occur during El Niño-Southern Oscillation (ENSO) events originating in the Eastern Tropical Pacific (ETP). El Niñoinduced thermal stress is considered the primary threat to ETP coral reefs. An increase in the frequency and intensity of ENSO events predicted in the coming decades threatens a pan-tropical collapse of coral reefs. During the 1982-83 El Niño, most reefs in the Galapagos Islands collapsed, and many more in the region were decimated by massive coral bleaching and mortality. However, after repeated thermal stress disturbances, such as those caused by the 1997-98 El Niño, ETP corals reefs have demonstrated regional persistence and resiliency. Using a 44-year data set (1970-2014) of live coral cover from the ETP, we assess whether ETP reefs exhibit the same decline as seen globally for other reefs. Also, we compare the ETP live coral-cover rate of change with data from the maximum Degree Heating Weeks experienced by these reefs to assess the role of thermal stress on coral reef survival. We find that during the period 1970-2014, ETP coral cover exhibited temporary reductions following major ENSO events, büt no overall decline. Further, we find that ETP reef recovery patterns allow coral to persist under these El Niño-stressed conditions, often recovering from these events in $10-15$ years. Accumulative heat stress explains $31 \%$ of the overall annual rate of change of living coral cover in the ETP. This suggests that ETP coral reefs have adapted to thermal extremes to date, and may have the ability to adapt to near-term future climate-change thermal anomalies. These findings for ETP reef resilience may provide general insights for the future of coral reef survival and recovery elsewhere under intensifying El Niño scenarios. 


\section{KEYWORDS}

Climate change, coral cover, coral reefs, degree heating weeks, Eastern Tropical Pacific, ecosystem resilience, ENSO, thermal stress

\section{ORIGINAL RESEARCH}

Worldwide, coral cover is declining as reefs are affected by human activities, with compelling evidence of basin-wide coral cover decline in the Indo-Pacific (Bruno \& Selig, 2007), the Great Barrier Reef (De'ath, Fabricius, Sweatman, \& Puotinen, 2012) and the Caribbean (Gardner, Cote, Gill, Grant, \& Watkinson, 2003). Although Hughes (2018) has suggested that returning reefs to past configurations is no longer an option, in the long-term, if local stressors such as pollution and overfishing are managed, multiple trajectories of reef recovery may still possible (Lamy, Galzin, Kulbicki, Lison de Loma, \& Claudet, 2016). After extreme recurrent disturbances, coral reefs may show limited or no recovery, may undergo a phase shift from a coraldominated state to a macroalgal or cyanobacteria-dominated alternative stable state (Mumby, 2009), or remain below a certain coral-cover threshold (e.g., 10\% for Caribbean reefs; Bozec \& Mumby, 2015), limiting their functionality.

El Niño Southern Oscillation (ENSO) events are naturally occurring phenomena in the Pacific Ocean consisting of two distinct states, El Niño and La Niña, with warmer and colder water in the Eastern Tropical Pacific (ETP), respectively (Clarke, 2014). ENSO events change the hydrology of the Tropical Pacific Basin and affect biological processes such as productivity and population dynamics of coral reef organisms (Glynn, Mones, Podestá, Colbert, \& Colgan, 2017). During ENSO states, the sea surface temperature (SST) can exceed the upper and lower thermal limits of reef-building corals, disrupting their coral-algal symbiosis, and causing bleaching and mass mortality (Hughes, Anderson, et al., 2018). On a geological time-scale, ENSO events have been a common feature of the Pacific Ocean since 12 my ago (Zhang, Pagani, \& Liu, 2014). Palaeoecological evidence suggests that permanent El Niño conditions may have occurred during the Holocene, causing the temporary collapse of ETP coral reefs (Toth et al., 2012). The last century has been characterized by fewer, but stronger, El Niño events. These events have produced the most extreme years of thermal stress on ETP coral reefs (Freund et al., 2019), and are now acknowledged to exert the primary control 
100 over coral cover changes at broad spatiotemporal scales within the ETP (Wang, Deser, 101 Yu, DiNezio, \& Clement, 2017).

102 Approximately $93 \%$ of the heat trapped in the atmosphere by anthropogenic 103 greenhouse gasses is transferred directly into the ocean (Cheng, Abraham, Hausfather, $104 \&$ Trenberth, 2019). ENSO events are predicted to increase in frequency and intensity 105 (Cai et al., 2018; Wang et al., 2017), potentially generating recurring thermal stress and 106 mass bleaching events in coral reef ecosystems (Hughes, Kerry, et al., 2018). The most 107 recent climate-change assessment therefore predicts a very high likelihood of 108 irreversible damage to coral reefs worldwide (Heron, Maynard, van Hooidonk, \& Eakin, 109 2016). The extreme El Niño events of 1982-83, 1997-98 and 2015-16 were 110 characterized by exceptional warming (Oceanic El Niño Index > 2.0). Notably, the 111 1982-83 E1 Niño in the ETP triggered massive coral bleaching and mortality and caused 112 the extirpation of coral populations in several locations such as the Galápagos Islands 113 (Glynn, 1990). In addition to the thermal stress caused by ENSO events, ETP coral reefs 114 experience other harsh environmental conditions in the region such as low aragonite 115 saturation state (i.e., acidification) and high- $p \mathrm{CO}_{2}$ (Manzello et al., 2008), as well as 116 high fluctuations in nutrient levels, tidal amplitude, and aerial exposure during extreme 117 low tides (Zapata, Rodríguez-Ramírez, Caro-Zambrano, \& Garzón-Ferreira, 2010).

118 In the ETP, coral assemblages are isolated, relatively poorly developed, and 119 dominated by a few coral genera. They have been proposed as analogues of future 120 environmental conditions under global warming and ocean acidification scenarios 121 (Manzello et al., 2008). After the massive coral mortality of El Niño 1982-83, it was 122 hypothesized that many ETP coral reefs would collapse due to slow recovery, disrupted 123 reproductive activity, and recruitment limitations (Guzman \& Cortes, 2007). However, 124 after both the 1982-83 and 1997-98 El Niño events, coral reef recovery did occur 125 throughout the ETP, but in a temporally and spatially heterogeneous manner (Palacios $126 \&$ Zapata, 2014). For example, while reefs in Colombia (Zapata, 2017), Costa Rica 127 (Guzman \& Cortes, 2007) and Panama (Glynn, Enochs, Afflerbach, Brandtneris, \& 128 Serafy, 2014) have recovered to pre-disturbance coral cover values, in an extreme 129 scenario in the southeastern Galapagos Islands, recovery has been impaired by an 130 initially low coral cover, limited recruitment, high rates of bioerosion by corallivores 131 (Edgar et al., 2010), and by a reduced carbonate ion concentration which has decreased 132 coral calcification (Manzello et al., 2015). 

mangrove forests, seagrass beds, and coral reefs would be useful for ETP countries to quantify the economic goods and environmental services provided by them. However, unlike other coral reefs around the world, it is unknown if coral cover in the ETP is declining. This occurs, in part, because time-series data for ETP coral cover have not been collected or summarized. Identifying the factors driving reef recovery or decline is critical for defining the conservation strategies necessary to protect coral reefs in the region (Romero-Torres, Acosta, \& Treml, 2017). Here, we present a 44-year live coral cover trend analysis for the ETP coral reefs from an exhaustive literature review of empirical data to test two hypotheses: 1) Whether coral reefs of the ETP are following the global trend of live coral cover decline through time, and 2) If repeated exposure to ENSO-induced heat stress is associated with regional trends in live coral cover.

Analysis of coral cover data. To obtain the live coral cover data (defined as the percent of reef substrate covered by living scleractinian and milleporine hard corals, and

150 hereafter referred to as coral cover), we performed a systematic search of scientific literature using several digital libraries spanning the years 1960-2018 (see SI for detailed methods).

From 1130 compiled documents, we selected 78 published studies that met our inclusion criteria for the analysis of coral cover (Table S3). We extracted the coral cover data from tables, figures, and research statements. To structure the extracted data hierarchically, we followed the definitions of Jackson, Donovan, Cramer, and Lam (2014) in the following: biogeographical provinces (3 levels), regions (16 levels), sea surface temperature regimes (4 levels), countries ( 8 levels), along with location (54 levels), site (177 levels), years (44), coral cover (\%), algal cover (\%), and sampling technique (see Fig. 1). Three time-intervals were selected, based on the onset of highintensity El Niño events (1973-82, 1983-97, and 1998-2014). We developed a timeseries of coral cover data with 568 observations, using the site as the minimum geographical unit (i.e., one or more surveys at the same coordinates on the same reef; Jackson et al., 2014). There were no data available for 1973, from the Guayaquil region, nor sufficient published coral cover data to analyse the most recent El Niño event 2015- 
166 16, although data on this event are now starting to be published (Alvarado et al., 2020;

167 Cruz-García, Rodríguez-Troncoso, Rodríguez-Zaragoza, Mayfield, \& Cupul-Magaña, 168 2020). Figure S1 describes the number of surveys by region and year.
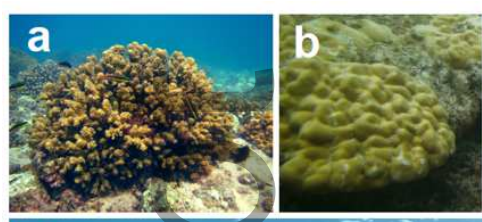

d
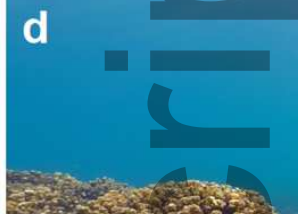

\begin{abstract}
.
\end{abstract}

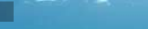

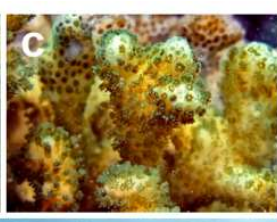

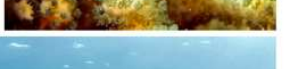

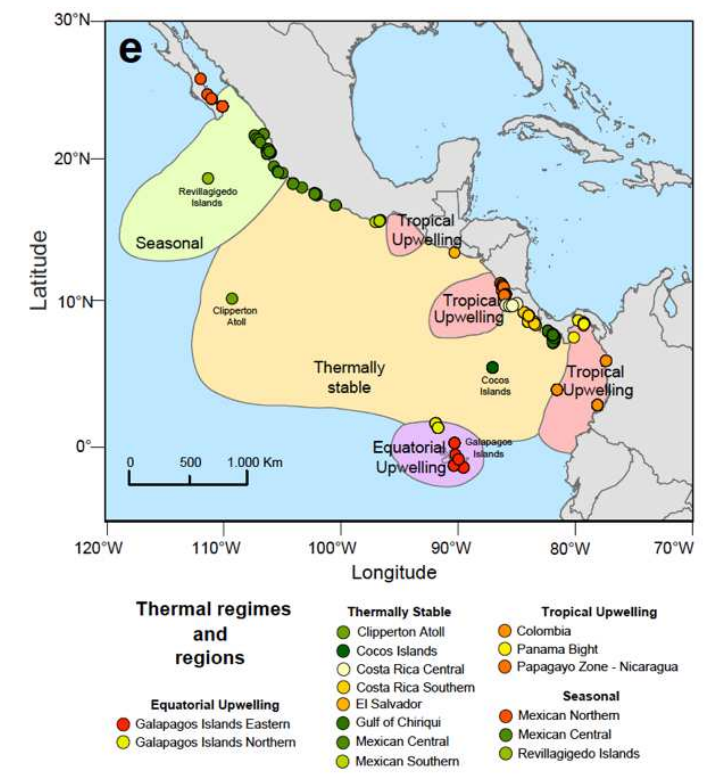

170 FIGURE 1 Coral assemblages in the Eastern Tropical Pacific are some of the most

171 depauperate reefs in the tropics but include 42 species of symbiotic scleractinian corals.

172 Coral assemblages in the ETP are dominated by dense clonal stands of Pocillopora and

173 stands of massive corals in the genera Porites, Pavona, and Gardineroseris. (a)

174 Pocillopora sp., (b) Porites lobata, (c) Pocillopora sp. close-up (d), coral assemblages

175 on the Gulf of California, México (images by David A. Paz-García). (e) Map of the

176 study region; color shading indicates the four thermal regimes and the 16 regions (dots)

177 of surveyed reefs.

179 Statistical analysis and limitations. We aggregated the coral cover data by calculating

180 the mean coral cover per site/year, then the mean coral cover per location/year, and,

181 finally, the mean coral cover per region/year (response variable). We added, as a factor

182 to the coral cover data, four distinct thermal regimes (Equatorial Upwelling, Thermally

183 Stable, Tropical Upwelling, and Seasonal). For an explanation of the thermal regimes

184 see Romero-Torres et al. (2017) and references therein. Since the coral cover data have

185 missing years, we tested if data were missing completely at random using IBM-SPSS

186 Statistics version 22 (see SI). To test the hypotheses that live coral cover declined

187 through time for each of five time-intervals (1974-82, 1983-97, 1998-2014, 1983-2014

188 and 1970-2014), we used generalized linear mixed models (GLMM) in R (version

189 3.5.1) with fixed (year and thermal regime) and random (region) effects, applying the 
190 Statistical Package lme4 (version 3.1-137). Raw data of coral cover change proportions were used without applying any transformation.

Our coral cover analysis has three significant limitations. The first is that including different sampling techniques (e.g., chain transects, point-intercept line transects, video belt transects, and quadrat samples) could potentially increase the variance between sample groups. However, the inclusion of these different percent cover estimators provides a robust estimate for region-wide analysis of coral cover and makes our work comparable to previous studies on other coral reefs where these techniques have also been used (Moritz et al., 2018) and successfully compared (Morrison et al., 2012).

The second potential limitation stems from the inclusion of several different sampling designs used in these disparate field surveys. We did not differentiate coral cover data based on the sampling design, such as the number of replicates, the reef zones sampled (back reef, fore-reef, or reef crest) or information on species relative abundances. Many other studies have omitted these details as well. Aggregation of these surveys is justified by the broad scale nature of the questions asked and by the fact that most ETP coral reefs are homogeneous, structurally simple, low-diversity fringing reefs, concentrated in shallow ( $<15 \mathrm{~m}$ ) water (Fig. 1) (Romero-Torres et al., 2017). The third limitation derives from the fact that our time series analysis does not result from repeat sampling of the same reefs through time, but instead from sampling several different reefs, but within the same region, through time. With the exception of the four most consistently monitored sites (see Figure S3), our coral cover data do come from a variety of sources. However, given the large number of data points from each region and the homogeneity of reefs across the entire basin, our methods did successfully capture broad-scale trends that occurred there, such as widespread coral mortality following the 1982-83 El Niño, as well as prominent periods of coral recovery.

218 Thermal stress and annual rate of change in coral cover. We examined the 219 relationship between the accumulated thermal stress and the annual rate of coral cover change (hereafter referred to as coral cover change) from 1982 to 2014. Ocean surface temperature satellite data began after 1982. Following Houlahan, Findlay, Schmidt, Meyer, and Kuzmin (2000), we estimated the year-on-year annual rates of coral cover change as $\log (N+1)_{t+1}-\log (N+1)_{t}=\Delta N$, where $N$ is percent coral cover and $t$ is year of 
study, for sites with two consecutive years of cover data and sites separated by one year (e.g., 1997 and 1999).

We estimated the accumulated thermal stress in each site based on the maximum degree heating weeks (DHW) index (Liu, Strong, Skirving, \& Arzayus, 2006), that was calculated using daily SST data with $1 / 4^{\circ}$ spatial resolution from the NOAA High Resolution Optimal Interpolated Sea Surface Temperature (OISST)

230 (NOAA/OAR/ESRL PSD, Boulder, Colorado, USA; https://www.esrl.noaa.gov/psd).

231 First, we calculated the maximum monthly mean (MMM) SST at the grid point closest

232 to the study sites, using a long-term monthly climatology OISST data set from 1985-

233 2012. For each site and each month of each year, we calculated the average SST and

234 estimated the climatology for each month as the average temperature of all years' means 235 for that month. The MMM was obtained by selecting the highest monthly mean value of 236 the 1985-2012 climatology at each site. We used the daily OISST data for each site and 237 their respective MMM to estimate the DHW because temperatures $\sim 1^{\circ} \mathrm{C}$ above the 238 MMM are known to cause coral bleaching if the stress is prolonged (Liu et al., 2006); 239 therefore, we consider appropriate the use of that DHW limit in the ETP reefs to 240 measure the effect of thermal anomalies for this region. To do that, daily HotSpots 241 (SST-MMM) $\geq 1{ }^{\circ} \mathrm{C}$ were summed up for 12 consecutive weeks (Liu et al., 2006), and 242 this value divided by seven to convert degree heating days to DHW (DHW $=1 / 7 \times$ sum 243 of previous 84 daily HotSpot, HotSpot $\geq 1^{\circ} \mathrm{C}$ ) (DeCarlo \& Harrison, 2019). Finally, the 244 maximum DHW value reached during the year was selected to represent the maximum 245 accumulated heat stress for the period evaluated. SST data were extracted with the 246 package raster for R, and following climatology and DHW calculations were done in R 247 (version 3.5.1).

248 To test the hypothesis that the intensity of thermal stress drives the change in 249 coral cover across geographic and thermal regimes, we used a GLMM with random 250 intercepts for thermal regimes with DHW as a fixed effect. GLMMs were adjusted in R 251 (version 3.5.1) with the Statistical Package lme4 (Table S2). Raw data of coral cover change proportions was used without applying any transformation. 
256 Coral Cover trends. We found a non-significant increase in the live coral cover from 1970 to 2014 in the ETP (Table S1, Fig. 2b). ETP coral cover exhibits considerable variability, regardless of the time interval or subregion of analysis (Fig. S2). From 1970 to 2014 , the ETP multiannual regional coral cover fluctuated around a median of $30.3 \%$ and a mean of $30.5 \%(s d \pm 20.1$, including all natural and anthropic sources - see

261 Statistical analysis and limitations, Fig. 2b). Comprehensive monitoring datasets were 262 found in published studies for Uva Island (Glynn et al., 2014), Gorgona Island (Zapata, 2017), Costa Rica (Cortés, Jiménez, Fonseca, \& Alvarado, 2010; Guzman \& Cortes, 2001), and the Eastern Galapagos Islands (Fong, Smith, \& Muthukrishnan, 2017). We did not locate accessible and structured datasets in other ETP locations or countries. The 1982-83 El Niño was responsible for an abrupt decline in the mean ETP coral cover from $32.7 \%(s d \pm 21.8)$ to $7.1 \%(s d \pm 6.8)$ [Tukey-like test (TL): $t=-3.22, p$ $<0.01$ ], equivalent to a $25.6 \%$ decrease of live coral cover. During the second period following the 1982 E1 Niño event from 1983-1997, the mean coral cover increased significantly from $7.1 \%$ in 1983 to $33.9 \%(s d \pm 19.3)$ in 1997 (TL: $t=3.40, p<0.01)$. In contrast to the significant coral loss between the El Niño years 1982 and 1983, we did not find a difference in the mean ETP coral cover between El Niño years 1997 and 1998 (TL: $t=1.679, p=0.09)$ compared to the previous period (1983-1997). The third time-interval 1998-2014, which had the highest monitoring sampling locations (more subregions and reefs surveyed per year), did not reveal an increasing or decreasing linear trend in mean coral cover (Table S1). Although coral cover increases slightly over the 44 years, this trend is not significant due to the data's high variability (Fig. 2b).

278 Even after the catastrophic coral die-off following the 1982-83 El Niño, we did not find evidence of a coral to macroalgal phase shift. This suggests basin-wide coral recovery, except on the northern Pacific coast of Costa Rica, where macroalgae cover did increase, suggesting a phase shift there (Alvarado et al., 2018). 

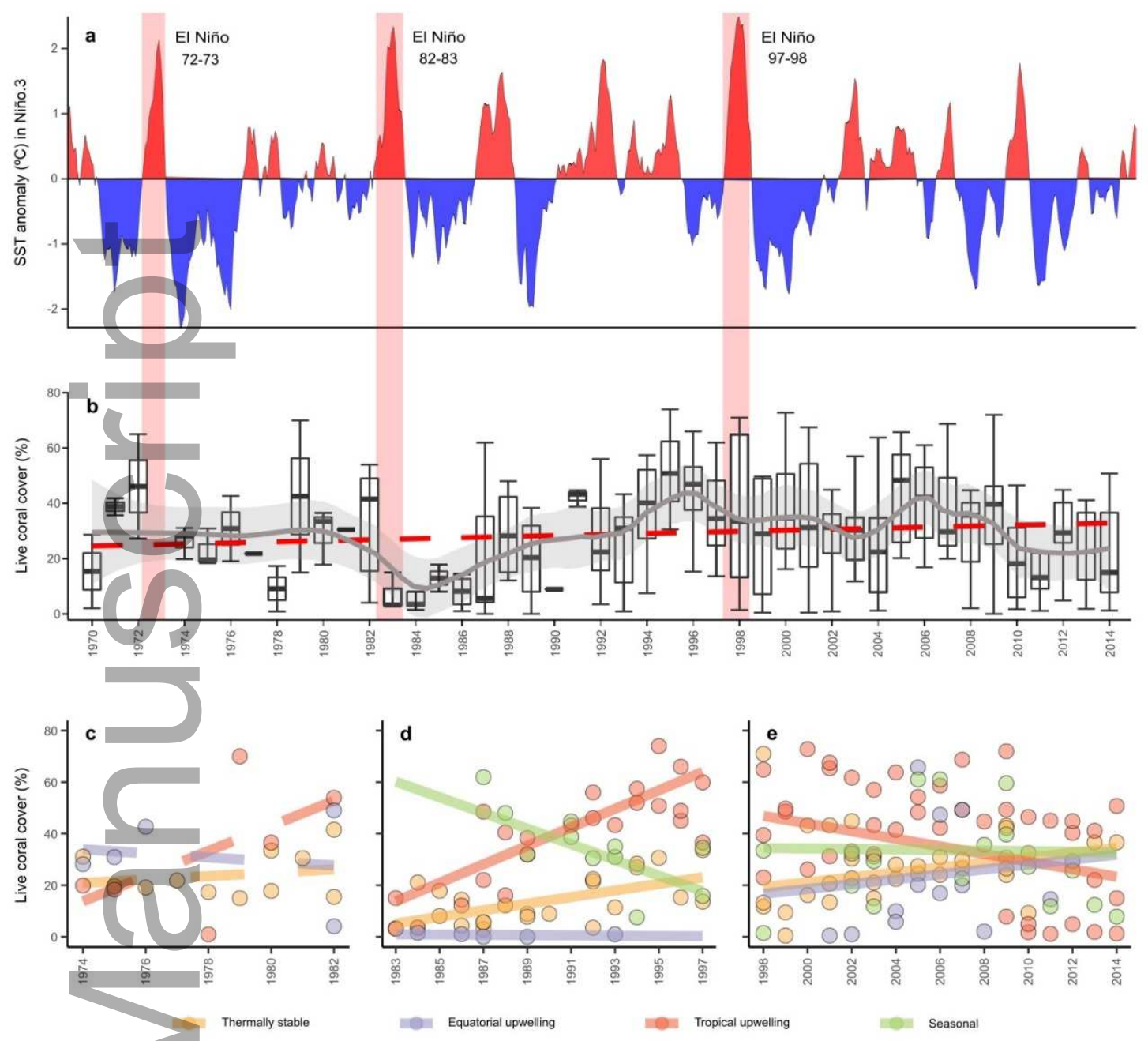

FIGURE 2 Illustration of the influence of most intense ENSO events on the coral

284 cover in the ETP. (a) The upper panel indicates the positive (red) and negative (blue)

285 SST anomalies in the Niño-3 region during 1971-2014 (NOAA Climate Prediction

286 Center's Extended Reconstructed Sea Surface Temperature ERSSTv5). The vertical

287 orange bars indicate the strongest El Niño events. (b) The panel displays, at the

288 horizontal axis, the 44-year live-coral cover aggregated at the region scale $(n=202)$ for

289 ETP coral reefs with its fitted linear trend (red dashed band). The fitted smooth line

290 trend represents the long-term cycles of loss and recovery (grey line with the best

291 polynomial fit with a $95 \%$ confidence level interval and a span $=0.2, p$ for year $=$

292 0.398). The vertical axis shows the live coral cover. Box plots describe the minimum,

293 maximum, interquartile ranges and median values of live-coral cover for each year.

294 Notice the abrupt decrease in coral cover after 1982-83 El Niño; a smaller decline

295 occurred after 1997-98. Random intercepts and random slopes models for the timeintervals: (c) 1974-1982 ( $p$ for Thermal regime $\times$ year $=0.265),(d) 1983-1997(p$ for 
297 Thermal regime $\times$ year $<0.001)$, and (e) 1998-2014 ( $p$ for Thermal regime $\times$ year $=$

298 0.036).

300 Relationship between change in coral cover and heat stress. Heat stress at each site 301 was estimated as the maximum accumulated DHW per year. Exposure beyond 8 DHWs

302 is likely to cause massive mortality (Liu et al., 2006). Our data show that there is a

303 weak, but significant positive linear relationship between thermal stress and the coral304 cover annual rate of change in the ETP from 1982 to 2014 (Conditional $R^{2}{ }_{G L M M}=0.313$, $305 n=133, p=0.002$, Fig. 3b, Table S2).

306 There was considerable variability both in the distribution of heat stress across

307 years in the ETP and the response of the coral cover changes as a function of DHW

308 (Fig. 3a). Nineteen out of 133 observations (15.03\%) of the coral-cover annual rate of

309 change experienced four or more DHW (Fig. 3b quadrants I and IV), and 13 out of these

31019 occurred during El Niño 1997-98. Ten records showed 8 or more DHW (two

311 overlapped), and these high heat stresses occurred at the Galapagos Islands (Santa Cruz

312 Island, DHW $=27.71$ in 1982) causing a catastrophic decline in coral cover, local

313 extirpation at many sites, and limited recovery; Gorgona Island in 1998 (DHW = 20.47)

314 and Malpelo Island in $2010(\mathrm{DHW}=13.10)$, the latter two produced only modest

315 deflections in the annual rate of change in coral cover at those sites. Eighty-four percent 316 of coral-cover annual change observations $(n=113)$ experienced fewer than 4 DHW

317 (Fig. 3b quadrants II and III), and 49 out of 58 of these observations are negative (Fig.

$3183 \mathrm{~b}$ quadrant III). We found negative annual rates of change in the seasonal thermal

319 regime (e.g., Mexican Northern and Mexican Central regions, green dots Fig. 3b). In the 320 seasonal thermal regime, 5 out of 14 of the negative cover-change rates occurred during 321 El Niño 1997-98. Between 2013 and 2015, the Gulf of California was affected by a 322 marine heatwave (Jacox et al., 2016); however, we did not find surveys in 2015 to 323 determine the coral cover change there. 

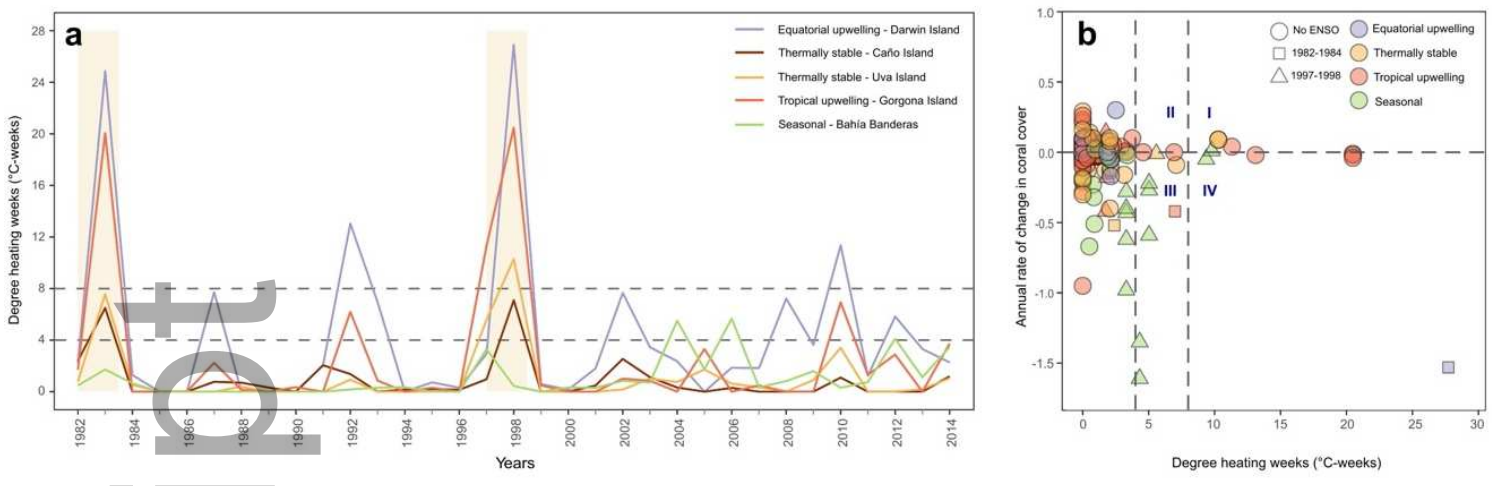

325 FIGURE 3 Heat stress and its effect on coral cover across the ETP. (a) The sequence of yearly maximum DHW experienced by the best-represented individual coral reefs sites from 1982 to 2014 . When cumulative thermal stress reaches $4{ }^{\circ} \mathrm{C}$-weeks and $8^{\circ} \mathrm{C}$ weeks or higher (horizontal dotted lines), bleaching is likely, as well as coral mortality from thermal stress (Liu et al., 2006), respectively. Although the thresholds were developed in seasonal systems, and are not universally applicable for equatorial regions, they are still useful for separating responses into well-defined heat-stress groups. (b) The association between the maximum DHW and the coral cover change at each of four thermal regimes (dot colors as Fig. 2). Each point $(n=133)$ represents the DHW and the coral cover annual rate of change per individual coral reef site. The horizontal dotted line divides the positive $(\geq 0)$ and the negative $(<0)$ rate of change caused by coral growth or mortality, respectively. The vertical dotted line indicates the DHW thresholds of $4^{\circ} \mathrm{C}$-weeks and $8^{\circ} \mathrm{C}$-weeks, respectively. The vertical ( $\geq 8^{\circ} \mathrm{C}$-weeks) and horizontal dotted lines create four response quadrants: I) heat stress and positive coral cover change (gain in live coral cover, 3.0\% resilient response), II) no heat stress and positive coral cover change (42.85\%), III) no heat stress and negative coral cover change (loss in live coral cover, $49.62 \%$ ), and IV) heat stress and negative coral cover change (4.51\%).

\section{DISCUSSION}

345 Over the past 44 years, coral cover has not declined consistently across the ETP.

346 Instead, it exhibits long-term cycles of loss and recovery, with no consistent upward or 347 downward trend. Even though most of the reefs in the Galapagos collapsed, and many 348 others across the ETP were decimated after the 1982-83 E1 Niño, the remaining ETP reefs support the hypothesis that even high levels of heat stress did not kill them all. Between 1982 and 2014, heat stress preceded $31 \%$ of the instances of coral decline in 
the ETP. These localized and sporadic periods of coral loss, however, never translated into a long-term, region-wide decline. For instance, the globally severe El Niño of 1997-98 evidenced only slight declines in the ETP, and nowhere near the catastrophic response seen in the 1982-83 El Niño (Reyes-Bonilla, Carriquiry, Leyte-Morales, \& Cupul-Magana, 2002). Lastly, ETP reefs also demonstrate periods of coral cover stability (1999-2014), even after taking into account high temporal and local variability. Because we were able to successfully retrieve and analyse several quantitative archival ETP coral reef surveys, our dataset stands as a compelling example of the utility and necessity for data rescue and recovery of ecological information. We have transformed local field observations on coral cover into a much broader temporal and spatial view of coral reef dynamics. We have aligned this ecological meta-analysis precisely with physical oceanographic information on ENSO-induced heat stress. In the ETP, cycles of disturbance and recovery in live coral cover contrast strikingly with the almost monotonic decline of Caribbean coral reefs (Jackson et al., 2014); but, they bear similarities with trajectories of some reefs across the Indo-Pacific, which recovered their live coral cover after disturbances (i.e., they returned to a similar coral-dominated state) (Sheppard et al., 2017). While baseline information on ETP coral reefs demonstrates that massive coral mortalities have occurred across the region (Toth et al., 2012), our long-term analysis also shows that ETP reefs can produce coral assemblages with $30-$ $50 \%$ live-coral cover within decades of the disturbance. Because of this ability to recover from thermal stress, it would be valuable to identify the factors and processes that underpin this recovery.

We hypothesize that a combination of at least four factors promotes ETP reef resilience. The first factor is growth strategies of the dominant coral species; the second is the resistance to high and low-temperature stress conferred by thermotolerant dinoflagellate symbionts; the third is the heterogeneous distribution of high-light and high-temperature stresses across the complex geography of the ETP; and the fourth

378 factor is the possibility of ecological memory, or the degree to which present trajectory 379 of an ecosystem is shaped by its antecedent conditions (Peterson, 2002), exhibited by 380 other frequently stressed coral reef ecosystems (Hughes et al., 2019). These ideas are discussed below.

Our results are concordant with a 10-15 year recovery time observed for sites populated with fast-growing corals, good colonizers, and branching species such as pocilloporids and acroporids (Gilmour, Smith, Heyward, Baird, \& Pratchett, 2013). 
385 Coral assemblages in the ETP are dominated by rapidly-growing branching

386 pocilloporids and massive to encrusting poritids. These features lead to lower coral

387 species richness and lower functional redundancy as compared with reefs near centers

388 of coral biodiversity, characteristics that theoretically should lead to lower resilience

389 after disturbance events (McWilliam et al., 2018). However, pocilloporid colonies can

390 grow at extension rates of 2.24-4.55 $\mathrm{cm} \mathrm{yr}^{-1}$ (Tortolero-Langarica, Rodríguez-Troncoso,

391 Cupul-Magaña, \& Carricart-Ganivet, 2017), and can quickly recolonize, even on coarse-

392 sediment substrates through asexual reproduction by fragmentation creating thousands

393 of viable clones, and less frequently by sexual recruitment after disturbances (e.g.,

394 strawberry-coral model; (Williams, 1975). Rapid regrowth and recovery have been

395 reported for several El Niño damaged reefs in the Maldives (Pisapia et al., 2016) and

396 elsewhere in the Indian Ocean (Perry et al., 2015). In both cases, this recovery was led

397 by rapidly growing pocilloporids. Finally, a majority of survivors and new recruits on

398 regenerating and recovering coral reefs are broadcast spawners with additional high

399 potential for asexual growth, relatively long-distance dispersal, rapid growth rates, and a

400 capacity for frame-work construction (Baker, Glynn, \& Riegl, 2008); these are hallmark

401 characteristics of ETP pocilloporids. Environmental conditions in the ETP produce a

402 trade-off within the Pocilloporidae, between fast growth and low skeleton density.

403 Second, as is typical of other hermatypic scleractinians, corals in the ETP are

404 reliant on endosymbiotic algae for both their growth materials and energy reserves.

405 Over the past decades, Durusdinium glynnii (formerly Symbiodinium glynnii)

406 (LaJeunesse et al., 2018) has come to dominate the algal symbiont communities of

407 Pocillopora (Baker, Correa, \& Cunning, 2017), either by differential mortality of corals

408 hosting more temperature-sensitive symbionts (LaJeunesse et al., 2010) or by the

409 replacement of sensitive, less tolerant symbionts with the more temperature-tolerant $D$.

410 glynnii (symbiont shuffling) in colonies exposed to stressful conditions (Palacio Castro,

411 2019). These changes in the symbiont communities can increase Pocillopora resistance

412 to both cold (LaJeunesse et al., 2010) and heat bleaching (Glynn, Maté, Baker, \&

413 Calderón, 2001), as well as to elevated irradiance (LaJeunesse, Reyes-Bonilla, \&

414 Warner, 2007), resulting in coral communities better suited to survive under stressful

415 conditions. Research on the interaction between coral symbionts and harsh

416 environments should continue to be a priority for ETP research.

417 Third, the coral-cover cycles of disturbance and recovery observed in this study

418 occur under highly fluctuating environmental conditions in the ETP (1983 and 
thereafter). These harsh conditions are distributed stochastically in space and time across the complex geography of the ETP (Fig. 1), leading to difficulty in determining regional trends in coral cover. For example, the 1997-98 El Niño produced a major global mass-bleaching event, but whereas on several reefs bleaching and mortality were high (Bruno, Siddon, Witman, Colin, \& Toscano, 2001), on others, they were minimal

424 (Baker et al., 2008). Previously, the effect of solar insolation was noted in French 425 Polynesia (Mumby, Chisholm, Edwards, Andrefouet, \& Jaubert, 2001), where it was suggested that high cloud cover reduced radiative stress, thereby preventing mass bleaching in French Polynesia during the 1997-98 El Niño event, despite abnormally elevated water temperatures there. Even though the three major ENSO events (1982-83, 1997-98 and 2015-16) share features, such as the intensity of thermal stress throughout the ETP, each ENSO event shows unique coupled atmosphere-ocean features, temporal evolution, and physical forcing mechanisms (Capotondi et al., 2015).

Especially in the ETP, it is important to study the regional variation in naturally occurring thermal stress and the potentially synergistic relationship between cloudiness and thermal stress as a driver of coral bleaching and survival. For example, the Thermally Stable and Tropical Upwelling areas (yellow and red dots, respectively in Fig. 3b) are some of the cloudiest regions in the world (Wilson \& Jetz, 2016). In contrast, the Seasonal thermal-regime area (Gulf of California; green dot) possesses among the highest levels of solar irradiance year-round (Wilson \& Jetz, 2016). While we do not know if light stress influences the negative values of some coral-cover changes observed in the Seasonal regime (Fig. 3b), it could be easily argued that elevated cloudiness in the Thermally Stable area could explain why there was no mass bleaching in the last decade in the Panama Bight, despite frequent episodes of thermal stress in this same region (e.g., 2009 or 2014, Fig. 3a). generate a physiological response similar to that of heat stress and alter the coral-algae association causing bleaching and death. Seasonal cold-water episodes are frequent in the Tropical and Equatorial upwelling thermal regimes and have caused cold-water bleaching at Malpelo Island (Hernández, Reyes-Bonilla, \& Balart, 2010) and in the Gulf of California (Paz-García, Balart, \& García-de-Léon, 2012). A coral bleaching indicator similar to DHW but for cold water intrusions is warranted to detect these critical negative temperature anomalies in the ETP. 
Subaerial exposures during extreme low tides in 2019 caused dramatic bleaching episodes at Gorgona and Uva Island (Mejía-Rentería, Castellanos-Galindo, Osorio-

454 Cano, \& Casella, 2020), providing another factor that should be considered in the future as a potential driver of live coral cover in the ETP.

Seasonal upwelling is also common in the ETP. This can increase the chlorophyll- $a$ concentration (as measured by satellite data) and elevate water turbidity protecting coral communities from radiative stress. For example, some morphological and physiological responses in pocilloporid corals in the Gulf of California coincided with a shift of environmental conditions from low to high levels of chlorophyll- $a$ (i.e., from low to high turbidity) (Paz-García, Hellberg, García-De-León, \& Balart, 2015). Graham et al. (2015) identified nutrient levels as a strong contra-indicator of IndoPacific reef recovery following bleaching. In contrast, ETP coral reefs develop under a broad range of nutrient concentrations and productivity. Given the influence of nutrients and phytoplankton on water clarity and light penetration, this aspect of ETP oceanography may be an enabling, rather than a disabling factor for ETP reef growth and survival.

Finally, growing evidence suggests that repeated exposure to heat stress conditions reduces the cumulative impact of recurrent climate extremes (DeCarlo et al., 2019; Guest et al., 2012; Hughes et al., 2019). Coral survival and the increase of resistance to recurrent stressful conditions may be the product of genetic adaptation (Dixon et al., 2015; Thomas \& Palumbi, 2017) and epigenetic inheritance (Eirin-Lopez \& Putnam, 2019; Putnam \& Gates, 2015). Our data suggest that some of these mechanisms may be at work in the ETP, especially among the pocilloporids. For example, differential mortality of Pocillopora corals along the ETP in response of thermal stress seems to have selected genetically resistant coral-algal partnerships (i.e., Durusdinium-Clade D; LaJeunesse et al. (2010), while in areas of the Gulf of California these symbiont/host pairings are more flexible (Pettay, Wham, Pinzon, \& LaJeunesse, 2011). Additionally, differential geographic connectivity pathways in dominant reef480 building corals in the ETP (Romero-Torres, Treml, Acosta, \& Paz-García, 2018) may create coral population isolates with resistant genetic varieties. Although epigenetic studies have not yet been performed on corals in situ in the ETP region, Pocillopora corals have shown positive responses to climate change stressors in offspring when their parents were conditioned (Eirin-Lopez \& Putnam, 2019; Putnam \& Gates, 2015). Thus, corals of the ETP are routinely exposed to thermal stress with a broad range of 
environmental conditions. This environmental heterogeneity may therefore contribute to this region's resilience and potential for near-term survival as coral reefs elsewhere succumb.

Based on our 44-year time-series analysis, coral reefs in the ETP region, when considered as a whole, have not declined in coral cover over the last 44 years despite occasional pulses of mortality, unlike elsewhere in the Caribbean and Indo-Pacific. We propose that the growth potential, algal symbiont composition, and thermal response characteristics of ETP pocilloporid corals, contribute to ETP reef resiliency. Whether or not the coral reef recovery mosaic which routinely exists across the ETP will produce full ecosystem recovery and function after every bleaching event will depend on factors such as (1) the degree of coral loss, (2) the species composition of the surviving reef, and (3) the dynamic balance of reef accumulation and bioerosion (Baker et al., 2008). At least, for now, patterns of recovery and resilience in the ETP are likely to persist across the complex topography and high oceanographic variability of this region. Unlike the bleaching and mass mortalities that inevitably follow exceptional temperature extremes elsewhere in the tropics, frequent El Niño events in the ETP have not produced a regional oceanographic environment in which coral reefs can no longer survive.

\section{ACKNOWLEDGMENTS}

We gratefully acknowledge the financial support provided by Colciencias and Colfuturo (Scholarship for Doctoral Studies - 528 to MRT and 529 to AMPC), by the Pontificia Universidad Javeriana, Facultad de Ciencias (ID PPTA 4135 and 4159), by UNGRD (9677-PPAL001-770-2019), and by a grant from the Kirbo Charitable Trust. We thank Cristian Gomez for summarizing coral cover data, as well as Princeton University and the Smithsonian Tropical Research Institute-Panama for its field assistantship in Coiba's Island and a Smithsonian pre-doctoral fellowship to J.W. Porter. Likewise, we thank the members of the Strategic Marine Ecosystems Laboratory at the Javeriana University and the comments of Elvira Alvarado, Hector Reyes-Bonilla, Jürgen Guerrero, Juan Sánchez, Maria Echeverry, and Kaz Uyehara, which significantly improved this work. Lastly, we thank Wilmar Torres (Universidad del Valle, Colombia) and Castor Guisande (Universidad de Vigo, Spain) for their statistical advice. 
521 The authors declare having no conflict of interest.

\section{DATA AVAILABILITY}

524 All data and code generated during the current study are available at https://doi.org/10.5281/zenodo.3744864

526

527

\section{ORCID}

528

Mauricio Romero-Torres

orcid.org/0000-0003-3282-0372

529

Alberto Acosta

orcid.org/0000-0001-9269-1547

530

Ana M. Palacio-Castro

orcid.org/0000-0002-0821-0286

531

Eric A. Treml

orcid.org/0000-0003-4844-4420

532

Fernando A. Zapata

orcid.org/0000-0001-8989-4458

533 David A. Paz-García

orcid.org/0000-0002-1228-5221

534 James W. Porter

orcid.org/0000-0002-4814-6290

535

536

537

538

539

Alvarado, J. J., Beita-Jiménez, A., Mena, S., Fernández, C., Cortés, J., Sánchez-

\section{Bibliography}

543

544

545

546

547

548 Noguera, C., .. . Guzmán-Mora, A. G. (2018). When conservation can keep up with development's pace: Health status of coral ecosystems in the North Pacific of Costa Rica. Revista de Biologia Tropical, 66(1), 280-308. https://doi.org/10.15517/rbt.v66i1.33300

Alvarado, J. J., Sánchez-Noguera, C., Arias-Godínez, G., Araya, T., Fernández-García, C., \& Guzmán, A. G. (2020). Impact of El Niño 2015-2016 on the coral reefs of the Pacific of Costa Rica: the potential role of marine protection. Revista de Biologia Tropical, 68(S1), S271-S282. https://doi.org/10,15517/RBT.V68IS1.41190

Baker, A. C., Correa, A. M. S., \& Cunning, R. (2017). Diversity, Distribution and Stability of Symbiodinium in Reef Corals of the Eastern Tropical Pacific. In W. P. Glynn, P. D. Manzello, \& C. I. Enochs (Eds.), Coral Reefs of the Eastern Tropical Pacific (pp. 405-420). Dordrecht: Springer Netherlands. 
Baker, A. C., Glynn, P. W., \& Riegl, B. (2008). Climate change and coral reef bleaching: An ecological assessment of long-term impacts, recovery trends and future outlook. Estuarine, Coastal and Shelf Science, 80(4), 435-471. https://doi.org/10.1016/j.ecss.2008.09.003

Bozec, Y.-M., \& Mumby, P. (2015). Synergistic impacts of global warming on the resilience of coral reefs. Philosophical Transactions of the Royal Society B: Biological Sciences, 370(1659), 20130267. https://doi.org/10.1098/rstb.2013.0267

Bruno, J. F., \& Selig, E. R. (2007). Regional Decline of Coral Cover in the Indo-Pacific: Timing, Extent, and Subregional Comparisons. PLoS ONE, 2(8), e711. https://doi.org/10.1371/journal.pone.0000711

Bruno, J.F., Siddon, C. E., Witman, J. D., Colin, P. L., \& Toscano, M. A. (2001). El Niño related coral bleaching in Palau, Western Caroline Islands. Coral Reefs, 20(2), 127-136. https://doi.org/10.1007/s003380100151

Cai, W., Wang, G., Dewitte, B., Wu, L., Santoso, A., Takahashi, K., . . McPhaden, M. J.(2018). Increased variability of eastern Pacific El Niño under greenhouse warming. Nature, 564(7735), 201-206. https://doi.org/10.1038/s41586-018$\underline{0776-9}$

Capotondi, A., Wittenberg, A. T., Newman, M., Di Lorenzo, E., Yu, J. Y., Braconnot, P., ... Yeh, S. W. (2015). Understanding ENSO diversity. Bulletin of the American Meteorological Society, 96(6), 921-938. https://doi.org/10.1175/BAMS-D-13-00117.1

Cheng, L., Abraham, J., Hausfather, Z., \& Trenberth, K. E. (2019). How fast are the oceans warming? Science, 363(6423), 128-129. https://doi.org/10.1126/science.aav7619

Clarke, A. J. (2014). El Niño Physics and El Niño Predictability. Annual Review of Marine Science, 6(1), 79-99. https://doi.org/10.1146/annurev-marine-010213$\underline{135026}$

This article is protected by copyright. All rights reserved 
Cortés, J., Jiménez, C. E., Fonseca, A. C., \& Alvarado, J. J. (2010). Status and conservation of coral reefs in Costa Rica. Revista de Biologia Tropical, 58, 3350. https://doi.org/10.15517/rbt.v58i1.20022

Cruz-García, R., Rodríguez-Troncoso, A. P., Rodríguez-Zaragoza, F. A., Mayfield, A., \& Cupul-Magaña, A. L. (2020). Ephemeral effects of El Niño southern oscillation events on an eastern tropical Pacific coral community. Marine and Freshwater Research. https://doi.org/10.1071/MF18481

De'ath, G., Fabricius, K. E., Sweatman, H., \& Puotinen, M. (2012). The 27-year decline of coral cover on the Great Barrier Reef and its causes. Proceedings of the National Academy of Sciences. https://doi.org/10.1073/pnas.1208909109

DeCarlo, T. M., \& Harrison, H. B. (2019). An enigmatic decoupling between heat stress and coral bleaching on the Great Barrier Reef. PeerJ, 7, e 7473. https://doi.org/10.7717/peerj.7473

DeCarlo, T. M., Harrison, H. B., Gajdzik, L., Alaguarda, D., Rodolfo-Metalpa, R., D'Olivo, J., ... McCulloch, M. T. (2019). Acclimatization of massive reefbuilding corals to consecutive heatwaves. Proceedings of the Royal Society B: Biological Sciences, 286(1898). https://doi.org/10.1098/rspb.2019.0235

Dixon, G. B., Davies, S. W., Aglyamova, G. A., Meyer, E., Bay, L. K., \& Matz, M. V. (2015). CORAL REEFS. Genomic determinants of coral heat tolerance across latitudes. Science, 348(6242), 1460-1462. https://doi.org/10.1126/science.1261224

Edgar, G. J., Banks, S. A., Brandt, M., Bustamante, R. H., Chiriboga, A., Earle, S. A., . . . Wellington, G. M. (2010). El Niño, grazers and fisheries interact to greatly elevate extinction risk for Galápagos marine species. Global Change Biology, 16(10), 2876-2890. https://doi.org/10.1111/j.1365-2486.2009.02117.x

Eirin-Lopez, J. M., \& Putnam, H. M. (2019). Marine Environmental Epigenetics. Annual Review of Marine Science, 11(1), 335-368. https://doi.org/10.1146/annurev-marine-010318-095114 
608

609

610

611

612

613

614

615

616

617

618

619

620

621

622

623

624

625

626

627

628

629

630

631

632

633

634

635

636

637

Fong, P., Smith, T. B., \& Muthukrishnan, R. (2017). Algal Dynamics: Alternate Stable States of Reefs in the Eastern Tropical Pacific. In W. P. Glynn, P. D. Manzello, \& C. I. Enochs (Eds.), Coral Reefs of the Eastern Tropical Pacific: Persistence and Loss in a Dynamic Environment (pp. 339-367). Dordrecht: Springer Netherlands.

Freund, M. B., Henley, B. J., Karoly, D. J., McGregor, H. V., Abram, N. J., \& Dommenget, D. (2019). Higher frequency of Central Pacific El Niño events in recent decades relative to past centuries. Nature Geoscience. https://doi.org/10.1038/s41561-019-0353-3

Gardner, T. A., Cote, I. M., Gill, J. A., Grant, A., \& Watkinson, A. R. (2003). Longterm region-wide declines in Caribbean corals. Science, 301(5635), 958-960. https://doi.org/10.1126/science. 1086050

Gilmour, J. P., Smith, L. D., Heyward, A. J., Baird, A. H., \& Pratchett, M. S. (2013). Recovery of an isolated coral reef system following severe disturbance. Science, 340(6128), 69-71. https://doi.org/10.1126/science.1232310

Glynn, P.W. (1990). Coral mortality and disturbances to coral reefs in the tropical eastern Pacific. In P. W. Glynn (Ed.), Global ecological consequences of the 1982-83 El Nino-Southern Oscillation (pp. 55-126): Elsevier; Oceanography Series, 52 .

Glynn, P. W., Enochs, I. C., Afflerbach, J. A., Brandtneris, V. W., \& Serafy, J. E. (2014). Eastern Pacific reef fish responses to coral recovery following El Niño disturbances. Marine Ecology Progress Series, 495, 233-247.

https://doi.org/10.3354/meps10594

Glynn, P. W., Maté, J. L., Baker, A. C., \& Calderón, M. O. (2001). Coral bleaching and mortality in Panama and Ecuador during the 1997-1998 El Niño-Southern Oscillation event: Spatial/temporal patterns and comparisons with the 19821983 event. Bulletin of Marine Science, 69(1), 79-109.

Glynn, P. W., Mones, A. B., Podestá, G. P., Colbert, A., \& Colgan, M. W. (2017). El Niño-Southern Oscillation: Effects on Eastern Pacific Coral Reefs and Associated Biota. In W. P. Glynn, P. D. Manzello, \& C. I. Enochs (Eds.), Coral 
638 Reefs of the Eastern Tropical Pacific: Persistence and Loss in a Dynamic Environment (pp. 251-290). Dordrecht: Springer Netherlands.

Graham, N. A. J., Jennings, S., MacNeil, M. A., Mouillot, D., \& Wilson, S. K. (2015). Predicting climate-driven regime shifts versus rebound potential in coral reefs. Nature, 518(7537), 94-97. https://doi.org/10.1038/nature14140

Guest, J. R., Baird, A. H., Maynard, J. A., Muttaqin, E., Edwards, A. J., Campbell, S. J., . . Chou, L. M. (2012). Contrasting patterns of coral bleaching susceptibility in 2010 suggest an adaptive response to thermal stress. PLoS ONE, 7(3), e33353. https://doi.org/10.1371/journal.pone.0033353

Guzman, H. M., \& Cortes, J. (2001). Changes in reef community structure after fifteen years of natural disturbances in the Eastern Pacific (Costa Rica). Bulletin of Marine Science, 69(1), 133-149.

Guzman,H. M., \& Cortes, J. (2007). Reef recovery 20 years after the 1982-1983 El Niño massive mortality. Marine Biology, 151(2), 401-411. https://doi.org/10.1007/s00227-006-0495-x

Hernández, L., Reyes-Bonilla, H., \& Balart, E. F. (2010). Effect of coral bleaching induced by low temperature on reef-associated decapod crustaceans of the southwestern Gulf of California. Revista Mexicana de Biodiversidad, 81(SUPPL.), S113-S119.

Heron, S. F., Maynard, J. A., van Hooidonk, R., \& Eakin, C. M. (2016). Warming Trends and Bleaching Stress of the World's Coral Reefs 1985-2012. Scientific Reports, 6, 38402. https://doi.org/10.1038/srep38402

Houlahan, J. E., Findlay, C. S., Schmidt, B. R., Meyer, A. H., \& Kuzmin, S. L. (2000). Quantitative evidence for global amphibian population declines. Nature, 404(6779), 752-755. https://doi.org/10.1038/35008052

Hughes, T. P., Anderson, K. D., Connolly, S. R., Heron, S. F., Kerry, J. T., Lough, J. M., ... Wilson, S. K. (2018). Spatial and temporal patterns of mass bleaching of corals in the Anthropocene. Science, 359(6371), 80. https://doi.org/10.1126/science.aan8048 
667

668

669

670

671

672

673

674

675

676

677

678

679

680

681

682

683

684

685

686

687

688

689

690

691

692

693

694

695

696

Hughes, T. P., Kerry, J. T., Baird, A. H., Connolly, S. R., Dietzel, A., Eakin, C. M., . . Torda, G. (2018). Global warming transforms coral reef assemblages. Nature, 556(7702), 492-496. https://doi.org/10.1038/s41586-018-0041-2

Hughes, T. P., Kerry, J. T., Connolly, S. R., Baird, A. H., Eakin, C. M., Heron, S. F., . . Torda, G. (2019). Ecological memory modifies the cumulative impact of recurrent climate extremes. Nature Climate Change, 9(1), 40-43.

https://doi.org/10.1038/s41558-018-0351-2

Jackson, J., Donovan, M., Cramer, K., \& Lam, V. (2014). Status and trends of Caribbean coral reefs: 1970-2012. Retrieved from Gland, Switzerland.:

Jacox, M. G., Hazen, E. L., Zaba, K. D., Rudnick, D. L., Edwards, C. A., Moore, A. M., \& Bograd, S. J. (2016). Impacts of the 2015-2016 El Niño on the California Current System: Early assessment and comparison to past events. Geophysical Research Letters, 43(13), 7072-7080. https://doi.org/10.1002/2016GL069716

LaJeunesse, T. C., Parkinson, J. E., Gabrielson, P. W., Jeong, H. J., Reimer, J. D., Voolstra, C. R., \& Santos, S. R. (2018). Systematic Revision of Symbiodiniaceae Highlights the Antiquity and Diversity of Coral Endosymbionts. Current Biology, 28(16), 2570-2580.e2576. https://doi.org/10.1016/j.cub.2018.07.008

LaJeunesse, T. C., Reyes-Bonilla, H., \& Warner, M. (2007). Spring “bleaching” among Pocillopora in the Sea of Cortez, Eastern Pacific. Coral Reefs, 26(2), 265-270. https://doi.org/10.1007/s00338-006-0189-3

LaJeunesse, T. C., Smith, R., Walther, M., Pinzón, J., Pettay, D. T., McGinley, M., .. . Warner, M. E. (2010). Host-symbiont recombination versus natural selection in the response of coral-dinoflagellate symbioses to environmental disturbance. Proceedings of the Royal Society B: Biological Sciences, 277(1696), 2925-2934. https://doi.org/10.1098/rspb.2010.0385

Lamy, T., Galzin, R., Kulbicki, M., Lison de Loma, T., \& Claudet, J. (2016). Three decades of recurrent declines and recoveries in corals belie ongoing change in fish assemblages. Coral Reefs, 35(1), 293-302. https://doi.org/10.1007/s00338$\underline{015-1371-2}$

This article is protected by copyright. All rights reserved 
Liu, G., Strong, A. E., Skirving, W., \& Arzayus, L. F. (2006). Overview of NOAA coral reef watch program's near-real time satellite global coral bleaching monitoring activities. Paper presented at the Proceedings of the 10th International Coral Reef Symposium. June.

Manzello, D. P., Enochs, I. C., Bruckner, A., Renaud, P. G., Kolodziej, G., Budd, D. A., Glynn, P. W. (2015). Galápagos coral reef persistence after ENSO warming across an acidification gradient. Geophysical Research Letters, 41(24), 90019008. https://doi.org/10.1002/2014GL062501

Manzello, D. P., Kleypas, J. A., Budd, D. A., Eakin, C. M., Glynn, P. W., \& Langdon, C. (2008). Poorly cemented coral reefs of the eastern tropical Pacific: Possible insights into reef development in a high-CO2 world. Proceedings of the National Academy of Sciences, USA, 105(30), 10450-10455. https://doi.org/10.1073/pnas.0712167105

McWilliam, M., Hoogenboom, M. O., Baird, A. H., Kuo, C.-Y., Madin, J. S., \& Hughes, T. P. (2018). Biogeographical disparity in the functional diversity and redundancy of corals. Proceedings of the National Academy of Sciences, USA, 115(12), 3084-3089. https://doi.org/10.1073/pnas.1716643115

Mejía-Rentería, J. C., Castellanos-Galindo, G. A., Osorio-Cano, J. D., \& Casella, E. (2020). Subaerial exposure of coral reefs during spring low tides in the eastern Pacific. Bulletin of Marine Science, 96(1), 219-220. https://doi.org/10.5343/bms.2019.0085

Moritz, C., Vii, J., Lee Long, W., Tamelander, J., Thomassin, A., \& Planes, S. (Eds.). (2018). Status and Trends of Coral Reefs of the Pacific: Global Coral Reef Monitoring Network.

Morrison, J. M., Ruzicka, R., Colella, M. A., Brinkhuis, V. I., Lunz, K. S., Kidney, J. A., . . Porter, J. W. (2012). Comparison of image-acquisition technologies used for benthic habitat monitoring. Paper presented at the Proceedings of the 12th International Coral Reef Symposium (Cairns, QLD), Cairns, Australia. 
Mumby, P. J. (2009). Phase shifts and the stability of macroalgal communities on Caribbean coral reefs. Coral Reefs, 28(3), 761-773. https://doi.org/10.1007/s00338-009-0506-8

Mumby, P. J., Chisholm, J. R. M., Edwards, A. J., Andrefouet, S., \& Jaubert, J. (2001). Cloudy weather may have saved Society Island reef corals during the 1998 ENSO event. Marine Ecology Progress Series, 222, 209-216. https://doi.org/10.3354/meps222209

Palacio Castro, A. M. (2019). Abiotic controls on endosymbiotic algal communities and their implications for coral bleaching susceptibility and recovery. (Doctoral), University of Miami, Miami.

Palacios, M. d. M., \& Zapata, F. A. (2014). Fish community structure on coral habitats with contrasting architecture in the Tropical Eastern Pacific. Revista de Biologia Tropical, 62, 343-357. https://doi.org/10.15517/RBT.V62I0.16360

Paz-García, D. A., Balart, E. F., \& García-de-Léon, F. J. (2012, 9-13 July 2012). Cold water bleaching of Pocillopora in the Gulf of California. Paper presented the Proceedings of the 12th International Coral Reef Symposium, Cairns, Australia.

Paz-García, D. A., Hellberg, M. E., García-De-León, F. J., \& Balart, E. F. (2015). Switch between Morphospecies of Pocillopora Corals. The American Naturalist, 186(3), 434-440. https://doi.org/10.1086/682363

Perry, C. T., Murphy, G. N., Graham, N. A. J., Wilson, S. K., Januchowski-Hartley, F. A., \& East, H. K. (2015). Remote coral reefs can sustain high growth potential and may match future sea-level trends. Scientific Reports, 5, 18289.

https://doi.org/10.1038/srep18289

Peterson, G. D. (2002). Contagious Disturbance, Ecological Memory, and the Emergence of Landscape Pattern. Ecosystems, 5(4), 329-338. https://doi.org/10.1007/s10021-001-0077-1

Pettay, D. T., Wham, D. C., Pinzon, J. H., \& LaJeunesse, T. C. (2011). Genotypic diversity and spatial-temporal distribution of Symbiodinium clones in an 

abundant reef coral. Molecular Ecology, 20(24), 5197-5212. https://doi.org/10.1111/j.1365-294X.2011.05357.x

Pisapia, C., Burn, D., Yoosuf, R., Najeeb, A., Anderson, K. D., \& Pratchett, M. S. (2016). Coral recovery in the central Maldives archipelago since the last major mass-bleaching, in 1998. Scientific Reports, 6, 34720. https://doi.org/10.1038/srep34720

Putnam, H. M., \& Gates, R. D. (2015). Preconditioning in the reef-building coral Pocillopora damicornis and the potential for trans-generational acclimatization in coral larvae under future climate change conditions. The Journal of Experimental Biology, 218(15), 2365. https://doi.org/10.1242/jeb.123018

Reyes-Bonilla, H., Carriquiry, J. D., Leyte-Morales, G. E., \& Cupul-Magana, A. L. (2002). Effects of the El Nino-Southern Oscillation and the anti-El Niño event (1997-1999) on coral reefs of the western coast of México. Coral Reefs, 21(4), 368-372. https://doi.org/10.1007/s00338-002-0255-4

Romero-Torres, M., Acosta, A., \& Treml, E. (2017). The regional structure of spawning phenology and the potential consequences for connectivity of coral assemblages across the Eastern Tropical Pacific. ICES Journal of Marine Science, 74(3), 613624. https://doi.org/10.1093/icesjms/fsw218

Romero-Torres, M., Treml, E. A., Acosta, A., \& Paz-García, D. A. (2018). The Eastern Tropical Pacific coral population connectivity and the role of the Eastern Pacific Barrier. Scientific Reports, 8(1), 9354. https://doi.org/10.1038/s41598-018$\underline{27644-2}$

Sheppard, C., Sheppard, A., Mogg, A., Bayley, D., Dempsey, A. C., Roche, R., . . Purkis, S. (2017). Coral Bleaching and Mortality in the Chagos Archipelago. Atoll Research Bulletin, 613(2), 1-26. https://doi.org/10.5479/si.0077-5630.613

Thomas, L., \& Palumbi Stephen, R. (2017). The genomics of recovery from coral bleaching. Proceedings of the Royal Society B: Biological Sciences, 284(1865), 20171790. https://doi.org/10.1098/rspb.2017.1790 
Tortolero-Langarica, J. d. J. A., Rodríguez-Troncoso, A. P., Cupul-Magaña, A. L., \& Carricart-Ganivet, J. P. (2017). Calcification and growth rate recovery of the reef-building Pocillopora species in the northeast tropical Pacific following an ENSO disturbance. PeerJ, 5, e3191. https://doi.org/10.7717/peerj.3191

Toth, L. T., Aronson, R. B., Vollmer, S. V., Hobbs, J. W., Urrego, D. H., Cheng, H., . . Macintyre, I. G. (2012). ENSO Drove 2500-Year Collapse of Eastern Pacific Coral Reefs. Science, 337(6090), 81-84. https://doi.org/10.1126/science. 1221168

Wang, C., Deser, C., Yu, J.-Y., DiNezio, P., \& Clement, A. (2017). El Niño and Southern Oscillation (ENSO): A Review. In W. P. Glynn, P. D. Manzello, \& C. I. Enochs (Eds.), Coral Reefs of the Eastern Tropical Pacific: Persistence and Loss in a Dynamic Environment (pp. 85-106). Dordrecht: Springer Netherlands.

Wang, G., Cai, W., Gan, B., Wu, L., Santoso, A., Lin, X., . . McPhaden, M. J. (2017). Continued increase of extreme El Nino frequency long after $1.5^{\circ} \mathrm{C}$ warming stabilization. Nature Climate Change, 7(8), 568-572. https://doi.org/10.1038/nclimate3351

Williams, G. C. (1975). Sex and Evolution: Princeton University Press.

Wilson, A. M., \& Jetz, W. (2016). Remotely Sensed High-Resolution Global Cloud Dynamics for Predicting Ecosystem and Biodiversity Distributions. PLoS Biology, 14(3), e1002415. https://doi.org/10.1371/journal.pbio.1002415

Zapata, F. A. (2017). Temporal dynamics of coral and algal cover and their drivers on a coral reef of Gorgona Island, Colombia (Eastern Tropical Pacific). Revista de la Academia Colombiana de Ciencias Exactas, Físicas y Naturales, 41(160), 306318. https://doi.org/10.15517/rbt.v58i1.20025

Zapata, F. A., Rodríguez-Ramírez, A., Caro-Zambrano, C., \& Garzón-Ferreira, J. (2010). Mid-term coral-algal dynamics and conservation status of a Gorgona Island (Tropical Eastern Pacific) coral reef. Revista de Biologia Tropical, 58(Suppl.1), 81-94. https://doi.org/10.1126/science.1246172 
809

810

811

812
Zhang, Y. G., Pagani, M., \& Liu, Z. (2014). A 12-million-year temperature history of the Tropical Pacific Ocean. Science, 344(6179), 84-87. https://doi.org/10.1126/science.1246172
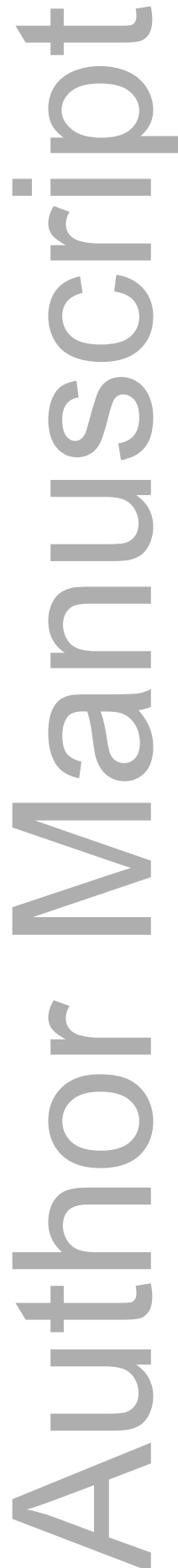

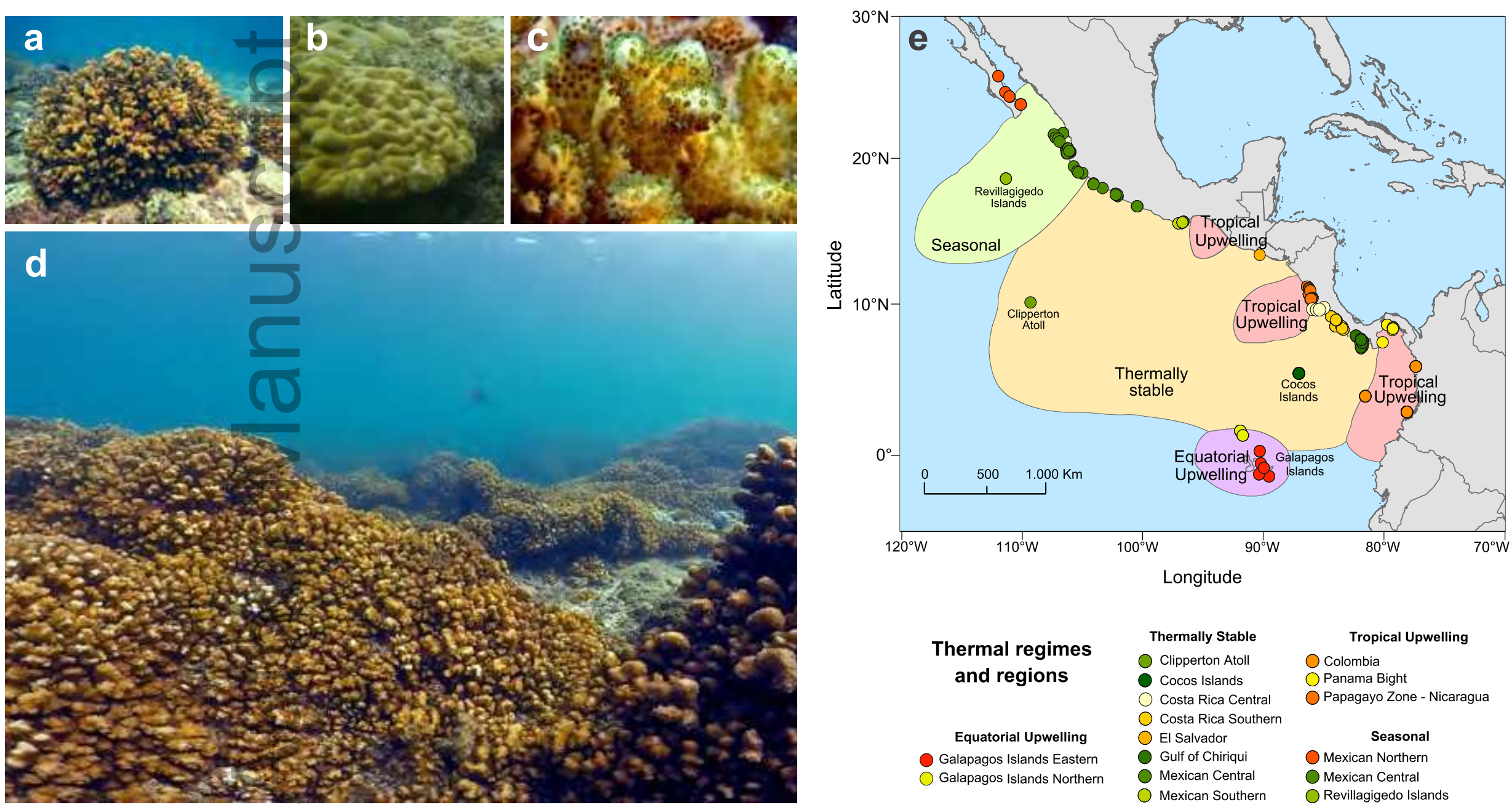

This article is protected by copyright. All rights reserved 

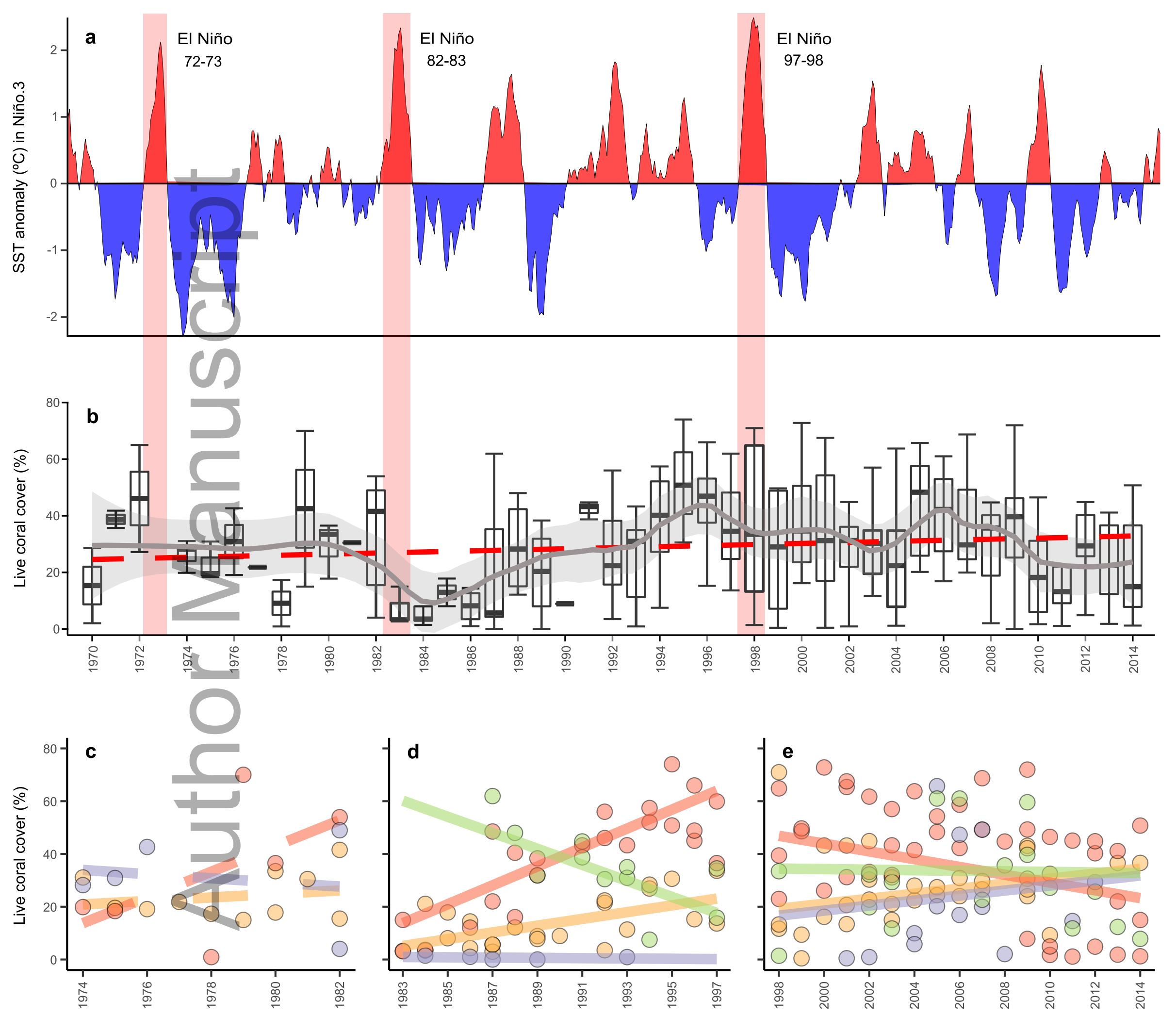

19u Thermally stable 


\section{University Library}

\section{- M M N E R VA A gateway to Melbourne's research publications}

Minerva Access is the Institutional Repository of The University of Melbourne

Author/s:

Romero-Torres, M;Acosta, A;Palacio-Castro, AM;Treml, EA;Zapata, FA;Paz-Garcia,

DA;Porter, JW

Title:

Coral reef resilience to thermal stress in the Eastern Tropical Pacific

Date:

2020-05-22

Citation:

Romero-Torres, M., Acosta, A., Palacio-Castro, A. M., Treml, E. A., Zapata, F. A., Paz-Garcia, D. A. \& Porter, J. W. (2020). Coral reef resilience to thermal stress in the Eastern Tropical Pacific. GLOBAL CHANGE BIOLOGY, 26 (7), pp.3880-3890. https://doi.org/10.1111/ gcb.15126.

Persistent Link:

http://hdl.handle.net/11343/275777 